\title{
PENGARUH PERSEPSI DUKUNGAN SOSIAL TERHADAP KESEJAHTERAAN DI SEKOLAH SISWA SMA
}

\author{
Ulifa Rahma, Rr. Karina Putri Pramitadewi, Faizah, \& Yuliezar Perwiradara \\ Fakultas Psikologi, Universitas Brawijaya, Ketawanggede, Kecamatan Lowokwaru, Malang 65145, Indonesia
}

Korespondensi:

e-mail: ulifa.rahma@ub.ac.id

\begin{abstract}
Recent studies suggest that school well-being is an important predictor of students' achievement. One of the determinants of school well-being is social support. This study aims to examine the role of perceived social support toward school well-being among senior high school students. A total of 304 students $\left(M_{\text {age }}=16.27 ; S D=.815\right)$ participated in this study and were approached through accidental sampling. Results indicate that perceived social support plays a significant role in determining the school well-being of high school students. Of the five identified sources of social support, perceived support from teacher was known to have the biggest contribution towards high school students' school well-being, while perceived support from peer groups has the smallest role towards their school wellbeing. The study concludes by recommending high schools to consider providing and fulfilling students' social support as an effort to maintain their school well-being and to encourage their performance.
\end{abstract}

Article history:

Received 23 April 2019

Received in revised form 6 May 2019

Accepted 13 April 2020

Available online 20 May 2020

\section{Keywords:}

peer support;

perceived social support;

school well-being;

senior high school;

students;

teacher support

\begin{abstract}
Abstrak - Studi-studi terbaru menunjukkan bahwa kesejahteraan di sekolah merupakan prediktor penting terhadap prestasi siswa. Salah satu determinan dari persepsi siswa terhadap tingkat kesejahteraannya di sekolah adalah persepsinya mengenai dukungan sosial dari lingkungan sekitarnya. Penelitian ini bertujuan untuk mengetahui apakah persepsi dukungan sosial berpengaruh signifikan terhadap kesejahteraan di sekolah siswa SMA. Sebanyak 304 siswa $\left(M_{\text {usia }}=16.27 ; S D=.815\right)$ berpartisipasi dalam studi ini; sampel diperoleh melalui teknik sampling aksidental. Hasil penelitian ini menunjukkan bahwa dukungan sosial berperan terhadap kesejahteraan di sekolah pada siswa SMA. Dari lima sumber persepsi dukungan sosial yang diukur, dukungan dari guru memiliki pengaruh terbesar terhadap kesejahteraan di sekolah siswa SMA, sedangkan dukungan dari sahabat menunjukkan pengaruh paling kecil. Hasil studi ini merekomendasikan pentingnya manajemen sekolah, terutama sekolah menengah atas, untuk memperhitungkan dan memenuhi dukungan sosial siswanya sebagai upaya untuk meningkatkan prestasi dan kesejahteraannya di sekolah.
\end{abstract}

Kata Kunci: dukungan dari guru; dukungan dari teman; kesejahteraan di sekolah; persepsi dukungan sosial; siswa SMA 


\section{PENDAHULUAN}

Sekolah adalah sebuah institusi pendidikan formal yang disediakan oleh pemerintah dengan fungsi sebagai tempat menuntut ilmu, pendewasaan moral, karakter, serta pengembangan minat dan bakat siswa (Santrock, 2014). Santrock (2014) menambahkan bahwa sekolah merupakan salah satu mikrosistem dalam sistem lingkungan bagi remaja, artinya sekolah sebagai tempat remaja menghabiskan banyak waktunya dengan segala aspek yang terdapat di dalamnya. Pusat Data dan Statistik Pendidikan dan Kebudayaan (2017) menjelaskan bahwa sebesar $63.7 \%$ anak usia 16 sampai 18 tahun bersekolah di Sekolah Menegah Sederajat, seperti SMA/MA dan SMK. Anak remaja di jenjang SMP, SMA, dan SMK umumnya menghabiskan waktu di sekolah sekitar 7 jam dalam sehari, artinya hampir sepertiga dari waktunya setiap hari dilalui di sekolah, sehingga tidak mengherankan apabila pengaruh sekolah terhadap perkembangan remaja cukup besar (Sarwono, 2015).

Tomyn dan Cummins (2010) mengilustrasikan tren umum yang menunjukkan bahwa remaja pertengahan secara signifikan memiliki kesejahteraan subjektif lebih rendah daripada remaja yang lebih muda. Seiring dengan bertambahnya usia, kesejahteraan siswa semakin rendah. Hal ini didukung oleh studi Konu dan Lintonen (2006) yang mengungkapkan bahwa kesejahteraan siswa SD dalam hal kondisi sekolah, hubungan sosial, dan sarana untuk pemenuhan diri lebih baik daripada siswa SMP dan SMA, sehingga menunjukkan bahwa pada siswa remaja yang berusia lebih tua memiliki kesejahteraan di sekolah yang lebih rendah. Konu dan Lintonen (2006) juga menjelaskan bahwa siswa sekolah lanjutan (sekolah menengah) sedang mengalami masa pubertas, di mana mereka membangun identitas dan citra diri mereka. Selama periode ini, motivasi sekolah mungkin berkurang diiringi dengan munculnya kesulitan berkonsentrasi, berkonfliknya hubungan dengan guru, kurang personalnya strategi pengajaran sekolah, dan penekanan lebih besar ditempatkan pada hasil akademik (Tobia, Greco, Steca, \& Marzocchi, 2019). Kesejahteraan di sekolah menjadi penting karena jika siswa sehat, merasa bahagia, dan sejahtera dalam mengikuti pelajaran di kelas, maka proses belajar dapat menjadi efektif dan siswa dapat memberikan kontribusi positif pada sekolah. Tujuan utama kesejahteraan di sekolah (school well-being) tidak hanya sekadar pemenuhan kesejahteraan siswa saja, tetapi juga pemenuhan prestasi, potensi, serta kemampuan fisik dan mental siswa (Konu \& Rimpela, 2002). 


\section{Kesejahteraan di Sekolah}

Variabel kesejahteraan di sekolah dikembangkan oleh Konu dan Rimpela (2002) yang awalnya merujuk pada model konseptual kesejahteraan yang dikemukakan oleh Allardt (1989). Allardt (1989) mendefinisikan kesejahteraan sebagai keadaan yang memungkinkan individu untuk memuaskan kebutuhan-kebutuhan dasarnya, yang mencakup kebutuhan material maupun nonmaterial. Berdasarkan konsep kesejahteraan tersebut, Konu dan Rimpela (2002) mengembangkan kesejahteraan dalam konteks sekolah melalui kajian terhadap beberapa literatur, seperti sosiologis, pendidikan, psikologis, dan peningkatan kesehatan, hingga akhirnya menghasilkan model kesejahteraan di sekolah. Konu dan Rimpela (2002) kemudian mendefinisikan kesejahteraan di sekolah sebagai keadaan sekolah yang memungkinkan individu memuaskan kebutuhan dasarnya, yang meliputi empat dimensi, yaitu kondisi sekolah (having), hubungan sosial (loving), pemenuhan diri (being), dan status kesehatan (health). Kesejahteraan di sekolah dapat dilihat dari dua indikator, yakni indikator objektif dan indikator subjektif. Indikator objektif didasarkan pada observasi eksternal, sedangkan indikator subjektif didasarkan pada ekspresi, sikap, dan persepsi individu terhadap kondisi lingkungannya. Data mengenai indikator subyektif ini dapat diperoleh melalui kuesioner, wawancara, atau esai siswa (Konu \& Rimpela, 2002). Konu dan Rimpela (2002) juga mengungkapkan bahwa kesejahteraan di sekolah dipengaruhi oleh lingkungan sekitar, keluarga, dan komunitas di mana siswa berada.

Kesejahteraan di sekolah menjadi penting karena jika siswa sehat, merasa bahagia, dan sejahtera dalam mengikuti pelajaran di kelas, maka proses belajar dapat menjadi efektif dan siswa dapat memberikan kontribusi positif pada sekolah (Konu \& Rimpela, 2002). Liu, Mei, Tian, dan Huebner (2016) menekankan bahwa pendidikan yang berkualitas harus memperhatikan pembelajaran akademik dan kebahagiaan siswanya. Kesejahteraan siswa di sekolah diketahui berkorelasi negatif dengan tingkat agresivitas (Nidianti \& Desiningrum, 2015) serta berkorelasi positif dengan efikasi diri siswa (Nanda \& Widodo, 2015).

Tujuan utama kesejahteraan di sekolah tidak hanya sekadar pemenuhan kesejahteraan siswa saja, tetapi juga pemenuhan prestasi, potensi, serta kemampuan fisik dan mental siswa (Konu \& Rimpela, 2002). Sebuah studi yang dilakukan untuk menganalisis hubungan antara keberhasilan akademik siswa dengan jenis dan sumber persepsi dukungan sosial (keluarga, teman, dan guru) menyatakan bahwa persepsi dukungan sosial siswa dari keluarga dan guru menentukan tingkat keberhasilan akademik mereka; siswa SMA dengan keberhasilan akademik yang lebih tinggi memiliki tingkat persepsi dukungan sosial yang lebih tinggi juga. Keberhasilan akademik adalah 
bentuk pemenuhan diri di sekolah yang merupakan salah satu dimensi dalam kesejahteraan di sekolah, yaitu pemenuhan diri (Akturk, 2015).

Deci dan Ryan (1985) mengemukakan teori self-determination yang menyatakan bahwa kesejahteraan seseorang ditentukan oleh kepuasan terhadap tiga kebutuhan dasar psikologis: kompetensi, otonomi, dan keterkaitan. Siswa mengevaluasi kesejahteraan di sekolah dalam arti sejauh mana pengalaman di sekolah dapat memenuhi kebutuhan dasar psikologis, termasuk kebutuhan untuk kompetensi, otonomi, dan keterkaitan. Kebutuhan untuk berelasi (need for relatedness) merupakan kebutuhan untuk merasa terhubung dengan aman dan dihargai oleh orang lain di lingkungan, sehingga dapat dikatakan bahwa kebutuhan untuk berelasi ini dipengaruhi oleh dukungan sosial. Dengan demikian, evaluasi dukungan sosial terhadap orang-orang penting di sekolah berhubungan positif dengan kesejahteraan di sekolah, artinya persepsi dukungan sosial dari orang tua, teman, dan guru dapat memenuhi kebutuhan siswa untuk berelasi, sehingga akhirnya berhubungan dengan kesejahteraan di sekolah (Tian dkk., 2013).

\section{Dukungan Sosial}

Salah satu variabel yang telah teridentifikasi sebagai prediktor kesejahteraan di sekolah adalah dukungan dari jejaring sosial, seperti keluarga dan sekolah. Dengan kata lain, kepuasan di sekolah berkaitan erat dengan dukungan sosial dari orang tua, guru, dan teman sekelas (Liu dkk., 2016). Munoz-Laboy, Severson, Perry, dan Guilamo-Ramos (2013) menjelaskan dukungan sosial merupakan persepsi individu mengenai sejauh mana dirinya diperhatikan, mendapatkan bantuan dari orang lain, dan merupakan bagian dari jaringan sosial yang mendukung. Dengan kata lain, jika si penerima mempresepsikan bahwa mereka memiliki dukungan sosial yang selalu tersedia bagi mereka, maka dukungan sosial tersebut akan semakin efektif.

Dalam konteks remaja di sekolah, jejaring sosial yang dimaksud adalah orang tua, guru, teman sekelas, sahabat, dan orang-orang di sekolah. Dukungan yang diberikan dapat berupa: dukungan emosional (menunjukkan kasih sayang, kepercayaan, empati), dukungan informasi (memberikan bantuan dan saran), dan dukungan dalam memberikan apresiasi (appraisal support) (memberikan penghargaan) (Malecki, \& Demaray, 2003).

\section{Dukungan Sosial dan Kesejahteraan di Sekolah}

Vedder, Boekaerts, dan Seegers (2005) menjelaskan bahwa persepsi dukungan sosial adalah prediktor kesejahteraan yang lebih baik daripada dukungan yang sebenarnya diberikan. Hal ini 
dikarenakan si penerima mungkin tidak menyadari semua bentuk dukungan sosial dari pemberi. Perilaku mendukung dalam konteks yang tidak sesuai dapat dipersepsikan bukan sebagai dukungan oleh penerima dan kurang bermanfaat sesuai dengan harapan si penerima.

Tian dkk. (2013) menjelaskan bahwa beberapa penelitian terhadap anak-anak dan remaja membuktikan adanya hubungan yang kuat antara persepsi dukungan sosial dan kesejahteraan di sekolah, meliputi dukungan dari orang tua, dukungan dari teman, dan dukungan dari guru. Liu dkk. (2016) menjelaskan bahwa siswa dengan persepsi dukungan sosial yang tinggi (khususnya terhadap guru) mencapai tingkat kesejahteraan di sekolah yang lebih tinggi. Oleh karena itu, persepsi dukungan sosial dari guru dan teman sekelas menjadi sangat penting dalam kesejahteraan di sekolah siswa (Liu dkk., 2016). Hal tersebut tidak mengherankan karena hubungan siswa dengan guru maupun dengan teman sekelas juga termasuk dalam salah satu dimensi kesejahteraan di sekolah, yaitu hubungan sosial. Liu dkk. (2016) juga memaparkan bahwa masing-masing sumber dukungan memiliki keunggulan yang berbeda pada tingkatan kelompok usia, misalnya sumber dukungan dari guru menjadi sumber yang paling kuat bagi siswa SD dan SMA, sementara sumber dukungan dari teman sekelas menjadi lebih kuat dibandingkan sumber dukungan dari guru bagi siswa SMP.

\section{Tujuan Studi}

Penelitian mengenai hubungan dukungan sosial dan kesejahteraan siswa remaja pertengahan belum pernah dilakukan di Indonesia, sehingga mendasari pentingnya dilakukan studi ini. Selain itu, penelitian Tomyn dan Cummins (2010) dan Konu dan Lintonen (2006) menjelaskan bahwa individu di rentang perkembangan remaja pertengahan memiliki kesejahteraan subjektif lebih rendah daripada siswa yang lebih muda dan kesejahteraan siswa di sekolah menengah lebih rendah daripada siswa SD. Oleh karena itu, penelitian ini bertujuan untuk melihat pengaruh persepsi dukungan sosial terhadap kesejahteraan di sekolah, khususnya pada siswa SMA.

\section{METODE}

\section{Partisipan}

Partisipan dalam penelitian ini adalah siswa SMA yang berjumlah 304 orang (Musia = 16.270; $S D=.815)$. Pengambilan sampel dilakukan dengan menggunakan teknik accidental sampling, yaitu partisipan yang secara kebetulan bertemu dengan peneliti dapat digunakan sebagai sampel sesuai sebagai sumber data, yaitu siswa SMA. Adapun, partisipan berasal dari dua sekolah 
yang berbeda, yaitu SMA Panjura Malang sebanyak 93 orang yang merupakan siswa kelas 11 dan SMAK Kolese Santo Yusup Malang sebanyak 211 orang yang merupakan siswa kelas 10 dan 11.

\section{Desain}

Penelitian ini menggunakan metode kuantitatif menggunakan uji regresi berganda. Uji regresi digunakan untuk mengetahui pengaruh persepsi dukungan sosial terhadap kesejahteraan di sekolah pada siswa SMA. Seluruh data diperoleh melalui survei.

\section{Prosedur}

Prosedur pelaksanaan yang dilakukan meliputi tahap persiapan dengan melakukan studi pustaka, menentukan metode penelitian, proses transadaptasi alat ukur dan tryout kepada 31 siswa dari kelas 11 (kelas 2 SMA) yang terbagi menjadi 18 orang laki-laki dan 13 orang perempuan untuk menguji validitas dan reliablitas alat ukur. Tahap pelaksanaan dilakukan dengan penyebaran skala penelitian secara langsung kepada siswa SMA yang ditemui secara klasikal dengan menyampaikan kepada partisipan maksud dan tujuan penelitian yang dilakukan, serta memohon kesediaan untuk menjadi partisipan dalam penelitian dengan cara menandatangani informed consent yang ada di lembar pertama pada skala yang diberikan. Peneliti sebelumnya menjelaskan petunjuk pengisian menggunakan kalimat yang mudah dipahami kepada siswa. Setelah data terkumpul, peneliti melakukan analisis data yang diperoleh.

\section{Instrumen}

\section{Dukungan Sosial}

Instrumen yang digunakan dalam penelitian ialah Child and Adolescent Social Support Scale (CASSS) yang dikembangkan oleh Malecki, Demaray, dan Elliott (2014) untuk mengukur persepsi dukungan sosial. Skala ini diadaptasi oleh peneliti dengan cara menerjemahkan skala dari Bahasa Inggris ke Bahasa Indonesia dibantu oleh dua akademisi bilingual yang independen. Kemudian, kedua hasil terjemahan dibandingkan satu sama lain. Setelah itu, skala dikonsultasikan kepada expert judgement, yaitu dosen bidang pikologi pendidikan, dan selanjutnya diterjemahkan kembali dari Bahasa Indonesia ke Bahasa Inggris.

CASSS mengukur persepsi dukungan sosial pada anak-anak dan remaja di kelas 3 sampai kelas 12 (setara dengan siswa kelas 3 SD hingga kelas 3 SMA) di Indonesia. Terdapat dua parameter dalam skala ini, yaitu parameter "sering" yang mengukur seberapa sering siswa 
merasakan dukungan yang diwakilkan dengan pertanyaan "Seberapa sering?" dan parameter "penting” yang mengukur seberapa pentingnya bagi siswa untuk merasakan dukungan tersebut yang diwakilkan dengan pertanyaan "Seberapa penting?". Partisipan memberi respons melalui skala Likert. Pada parameter "sering", rentang jawaban dibagi menjadi enam ( 1 = "Tidak Pernah", $6=$ "Selalu"), sedangkan parameter "penting” memiliki 3 pilihan jawaban ( 1 = "Tidak Penting", 3 = "Sangat Penting").

Skala ini terdiri dari total 60 butir yang terbagi proporsional ke dalam lima subskala yang merupakan sumber dukungan (orang tua, guru, teman sekelas, sahabat, dan orang-orang di sekolah). Butir-butir dalam setiap subskala merupakan pernyataan yang mewakili empat tipe dukungan sosial, yaitu emotional (butir 1-3), informational (butir 4-6), appraisal (butir 7-9), dan instrumental (butir 10-12). Peneliti melakukan pengujian instrumen yang meliputi uji validitas dan uji reliabilitas. Dalam penelitian ini, uji validitas yang dilakukan adalah face validity (validitas muka) dan untuk menguji reliabilitas melalui perhitungan rumus Cronbach's Alpha. Hasil uji reliabilitas CASSS dalam penelitian ini menunjukkan Cronbach's Alpha sebesar sebesar .934 untuk parameter “sering" dan .898 untuk parameter "penting".

\section{Kesejahteraan di Sekolah}

Skala yang digunakan untuk mengukur kesejahteraan di sekolah adalah School Well-being Profile (SWP) (Konu \& Rimpela, 2002) dan diadaptasi oleh peneliti dari Bahasa Inggris ke Bahasa Indonesia. Skala ini terdiri dari 79 butir dan terbagi menjadi empat dimensi kesejahteraan di sekolah, meliputi kondisi sekolah (26 butir), hubungan sosial (17 butir), pemenuhan diri (24 butir), dan status kesehatan (12 butir). Penelitian ini menggunakan School Well-being Profile yang memang diperuntukkan khusus bagi siswa SMA, di mana partisipan merespons melalui skala Likert dengan lima pilihan jawaban. Hasil uji reliabilitas SWP dalam penelitian ini menunjukkan Cronbach's Alpha sebesar .94.

\section{Teknik Analisis}

Uji distribusi data dilakukan dengan mengunakan uji normalitas menggunakan uji Kolmogorov-Smirnov dan uji linearitas menggunakan Test for Linearity terhadap data penelitian. Uji hipotesis dalam penelitian ini menggunakan multiple regression. Seluruh analisis dilakukan menggunakan program SPSS versi 25. 


\section{ANALISIS DAN HASIL}

\section{Gambaran Umum Subjek Penelitian}

Jumlah subjek dalam penelitian ini awalnya sebanyak 307 orang, tetapi terdapat tiga orang yang gugur karena tidak mengisi survei secara lengkap, sehingga subjek yang digunakan dalam penelitian ini menjadi 304 orang. Jumlah subjek berjenis kelamin perempuan sebesar 52.63\% dan laki-laki sebesar 47.37\%. Subjek dalam penelitian ini memiliki rentang usia 15-18 tahun, yang meliputi siswa dari kelas 10 (31.9\%) dan kelas 11 (68.1\%).

Tabel 1 merangkum gambaran perbandingan skor hipotetik dan skor empirik pada variabel penelitian.

Tabel 1.

Perbandingan Skor Hipotetik dan Skor Empirik

\begin{tabular}{lcccccccc}
\hline \multicolumn{1}{c}{ Variabel } & \multicolumn{4}{c}{ Nilai Hipotetik } & \multicolumn{4}{c}{ Nilai Empirik } \\
\cline { 2 - 9 } & Min. & Maks. & $\boldsymbol{M}$ & SD & Min. & Maks. & $\boldsymbol{M}$ & SD \\
\hline Persepsi Dukungan Sosial & & & & & & & & \\
Sering & 60 & 360 & 210 & 35 & 124 & 340 & 238.8 & 37.097 \\
Penting & 60 & 180 & 120 & 20 & 73 & 180 & 138.46 & 19.149 \\
Kesejahteraan di Sekolah & 0 & 316 & 158 & 17.24 & 101 & 288 & 200.82 & 30.233 \\
\hline
\end{tabular}

Setelah mendapatkan hasil dari skor hipotetik dan skor empirik, peneliti melakukan kategorisasi pada skor subjek berdasarkan norma ketentuan kategorisasi menurut Azwar (2015) yang melihat nilai hipotetik dengan ketentuan kategori rendah berada pada daerah keputusan $\mathrm{X}<(\mu$ - $\sigma)$, kategori sedang berada pada daerah keputusan $(\mu-\sigma) \leq \mathrm{X}<(\mu+\sigma)$, dan kategori tinggi berada pada daerah keputusan $(\mu+\sigma) \leq \mathrm{X}$. Hasil perhitungan dan kategorisasi skor subjek dirangkum dalam Tabel 2. Mengacu pada tabel tersebut, dapat diketahui bahwa data tingkat persepsi dukungan sosial sebagian besar subjek berada pada kategori sedang dan tingkat kesejahteraan di sekolah mayoritas subjek berada pada kategori tinggi. 
Tabel 2.

Kategorisasi Jenjang Skor Subjek

\begin{tabular}{|c|c|c|c|c|c|}
\hline Variabel & & Kategori & $\begin{array}{c}\text { Daerah } \\
\text { Keputusan }\end{array}$ & $\begin{array}{c}\text { Jumlah } \\
\text { Siswa }\end{array}$ & Persentase \\
\hline \multirow{8}{*}{$\begin{array}{l}\text { Persepsi } \\
\text { Dukungan Sosial }\end{array}$} & \multirow{4}{*}{ Sering } & Rendah & $X<175$ & 10 & $3.29 \%$ \\
\hline & & Sedang & $175 \leq X<245$ & 164 & $53.95 \%$ \\
\hline & & Tinggi & $245 \leq X$ & 130 & $42.76 \%$ \\
\hline & & & otal & 340 & $100 \%$ \\
\hline & \multirow{4}{*}{ Penting } & Rendah & $X<100$ & 7 & $2.3 \%$ \\
\hline & & Sedang & $100 \leq X<140$ & 174 & $57.24 \%$ \\
\hline & & Tinggi & $140 \leq X$ & 123 & $40.46 \%$ \\
\hline & & & otal & 340 & $100 \%$ \\
\hline \multirow{4}{*}{\multicolumn{2}{|c|}{ Kesejahteraan di Sekolah }} & Rendah & $\mathrm{X}<141$ & 6 & $1.97 \%$ \\
\hline & & Sedang & $141 \leq X<175$ & 48 & $15.79 \%$ \\
\hline & & Tinggi & $175 \leq X$ & 250 & $82.24 \%$ \\
\hline & & \multicolumn{2}{|c|}{ Total } & 340 & $100 \%$ \\
\hline
\end{tabular}

\section{Uji Asumsi}

Hasil uji normalitas menggunakan Teknik Kolmogorov-Smirnov menunjukkan bahwa data masing-masing variabel terdistribusi normal $(p>.05)$. Hasil uji linearitas dengan menggunakan Test for Linearity juga menunjukkan bahwa terdapat hubungan linear antara variabel persepsi dukungan sosial dengan kesejahteraan di sekolah $(p=.000)$.

\section{Analisis Uji Hipotesis}

Hasil uji multiple regression menunjukkan terdapat pengaruh signifikan antara persepsi dukungan sosial terhadap kesejahteraan di sekolah pada siswa SMA $(F=60.078 ; p=.000 ; E S=$ .285). Pada hasil dari uji hipotesis juga diketahui koefisien persepsi dukungan sosial dengan kesejahteraan di sekolah signifikan pada parameter sering dengan nilai signifikansi $.000(p<.05)$ dan bukan parameter penting dengan nilai signifikansi $0.200(p>.05)$.

Selanjutnya, analisis regresi dilakukan secara spesifik pada lima subskala sumber dukungan, yaitu orang tua, guru, teman sekelas, sahabat, dan orang-orang di lingkungan sekolah. Kelima sumber dukungan dalam persepsi dukungan sosial tersebut memiliki tingkatan pengaruh yang berbeda-beda terhadap kesejahteraan di sekolah. Hal tersebut dapat diketahui dari Tabel 3 berikut. 
Tabel 3.

Nilai Regresi Masing-Masing Sumber Parameter Persepsi Dukungan Sosial

\begin{tabular}{lcccccc}
\hline \multirow{2}{*}{ Sumber } & \multicolumn{2}{c}{$\boldsymbol{\beta}$} & \multicolumn{2}{c}{} & \multirow{2}{*}{$\boldsymbol{R}^{2}$} \\
\cline { 2 - 5 } & Sering & Penting & Sering & Penting & Simultan & \\
\hline Orang tua & .763 & .850 & .078 & .000 & .000 & .127 \\
Guru & .176 & 1.672 & .062 & .000 & .000 & .309 \\
Teman sekelas & -.236 & 1.174 & .541 & .000 & .000 & .124 \\
Sahabat & -1.055 & 1.171 & .732 & .012 & .000 & .108 \\
$\begin{array}{l}\text { Orang di lingkungan } \\
\text { sekolah }\end{array}$ & -.457 & 1.233 & .214 & .000 & .000 & .155 \\
\hline
\end{tabular}

Dengan demikian, dapat disimpulkan bahwa kelima sumber dukungan berpengaruh terhadap kesejahteraan di sekolah. Sumber dukungan yang memiliki effect size terbesar adalah guru $\left(R^{2}=\right.$ $.309)$, sedangkan yang terkecil ialah sahabat $\left(R^{2}=.108\right)$.

\section{DISKUSI}

Studi ini bertujuan untuk mengetahui pengaruh persepsi dukungan sosial dengan kesejahteraan siswa SMA di sekolah. Hal ini menunjukkan bahwa persepsi dukungan sosial berpengaruh signifikan terhadap kesejahteraan di sekolah siswa. Hasil ini serupa dengan studi sebelumnya (Tian dkk., 2013) bahwa ada hubungan yang kuat antara persepsi dukungan sosial dan kesejahteraan di sekolah, meliputi dukungan dari orang tua, dukungan dari teman, dan dukungan dari guru.

Jika dilihat dari kategorisasi yang telah dilakukan mengenai tingkat kesejahteraan di sekolah, mayoritas subjek studi berada pada kategori tinggi. Tingkat kesejahteraan di sekolah yang tinggi dapat pula dikarenakan oleh berbagai faktor, seperti cara pengajaran, pengalaman pembelajaran, dan lingkungan atau atmosfir sekolah. Konu dan Rimpela (2002) menjelaskan bahwa faktor yang memengaruhi tingginya kesejahteraan siswa, yaitu optimalisasi pengajaran dan pendidikan, pembelajaran, dan pendidikan yang diterima di lingkungan rumah.

Sementara itu, pada variabel persepsi dukungan sosial, mayoritas siswa mempersepsikan dukungan sosialnya dalam kategori sedang (baik dalam parameter "sering" maupun "penting") dengan komposisi data yang cukup tersebar pada berbagai kategori lainnya. Hasil ini didukung oleh penelitian Malecki dan Demaray (2003) yang menjelaskan adanya persepsi dukungan sosial, baik pada parameter penting dan sering, pada siswa SMA yang tersebar di berbagai tingkatan yang 
berbeda, mulai dari kategori tinggi, sedang, dan rendah. Oleh karena itu, dukungan sosial bagi siswa SMA dianggap penting dan perlu untuk sering diberikan.

Analisis tambahan terhadap kelima sumber dukungan pada persepsi dukungan sosial menunjukkan bahwa dukungan dari guru memiliki pengaruh terbesar terhadap kesejahteraan. Hal tersebut sesuai dengan penelitian Danielsen, Samdal, Hetland, dan Wold (2009) yang menyatakan bahwa siswa dengan persepsi dukungan sosial yang tinggi (khususnya terhadap guru) mencapai tingkat kesejahteraan di sekolah yang lebih tinggi. Penelitian Liu dkk. (2016) juga menunjukkan bahwa persepsi dukungan sosial dari guru menjadi sangat penting dalam kepuasan siswa di sekolah. Lebih lanjut, Liu dkk. (2016) memaparkan bahwa dukungan dari guru menjadi sumber yang paling kuat bagi siswa SD dan SMA. Beberapa penelitian juga menemukan perbedaan pada hubungan antara persepsi dukungan sosial dan kesejahteraan di sekolah ketika sumber dukungan dari orang tua, teman sebaya, dan guru diukur secara bersamaan dan hasil menunjukkan bahwa hubungan antara dukungan dari para guru menjadi yang terkuat terhadap kesejahteraan di sekolah siswa (Tian dkk., 2013).

Liu dkk. (2016) menjelaskan bahwa guru sering diibaratkan sebagai figur penting dalam kehidupan siswa karena perannya sebagai orang dewasa di sekolah yang mengetahui dan menunjukkan kepedulian mengenai banyak hal tentang siswa dan berfungsi sebagai penyedia dukungan sosial terhadap kesehatan mental siswa dalam konteks sekolah. Guru diidentifikasi sebagai tokoh utama dalam kehidupan sekolah siswa sehari-hari dan sumber utama dukungan sosial siswa di sekolah, khususnya terkait dengan hubungan interpersonal siswa. Dalam konteks kesejahteraan di sekolah, beberapa penelitian menunjukkan bahwa guru memberikan pengaruh penting, baik berkaitan dengan pencapaian tujuan akademik maupun pengaturan proses sosial emosional siswa (Vedder dkk., 2005). Vedder dkk. (2005) juga menyatakan bahwa kesejahteraan di sekolah berhubungan dengan ketersediaannya dukungan dari guru dalam mengatasi masalah pembelajaran pada siswa.

Dukungan yang kuat dan stabil dari guru sebagaimana dipersepsikan oleh subjek juga dapat disebabkan karena relasi dari keluarga dan teman kerap berkonflik pada individu yang berada di fase perkembangan ini (Tian dkk., 2013). Tian dkk. (2013) juga menyatakan bahwa dukungan dari guru dan orang tua secara signifikan berhubungan dengan kesejahteraan di sekolah pada remaja awal (usia 12-14 tahun), tetapi pada remaja pertengahan (usia 15-17 tahun) hanya dukungan dari gurulah yang secara signifikan berhubungan dengan kesejahteraan di sekolah. 
Penelitian ini melihat persepsi dukungan sosial terhadap kesejahteraan siswa SMA di sekolah. Namun, tidak menjelaskan mengenai aktualitas dukungan sosial yang diterima, apakah siswa secara langsung benar menerima dukungan sosial dari lingkungan sekitarnya. Meskipun Munoz-Laboy, Severson, Perry, dan Guilamo-Ramos (2013) menjelaskan bahwa tingkat keefektifan dukungan sosial akan semakin baik sesuai dengan sebaik apa si penerima mempersepsikannya, namun akan lebih baik apabila peneliti selanjutnya juga melihat dukungan sosial aktualitas yang diterima.

\section{SIMPULAN DAN SARAN}

\section{Simpulan}

Penelitian ini berhasil menunjukkan adanya pengaruh yang signifikan antara persepsi dukungan sosial dengan kesejahteraan di sekolah pada siswa SMA. Dari kelima sumber dukungan dalam persepsi dukungan sosial, guru memiliki pengaruh terbesar terhadap kesejahteraan di sekolah pada siswa SMA, diikuti oleh dukungan dari orang di lingkungan sekolah, orang tua, teman sekelas, dan sahabat.

\section{Saran Teoretis}

Penelitian selanjutnya diharapkan dapat menggunakan subjek penelitian pada jenjang pendidikan yang berbeda agar mendapatkan hasil yang lebih beragam dan dapat membandingkan subjek dari berbagai jenjang Pendidikan dan melihat dukungan sosial aktualitas (received) siswa di lingkungan sekitarnya.

\section{Saran Praktis}

Bagi sekolah, kesejahteraan siswa merupakan indikator penting untuk menjamin efektivitas pengalaman pembelajaran siswa, sehingga perlu diberi perhatian khusus. Studi ini menunjukkan bahwa kesejahteraan siswa dapat dipelihara dan ditingkatkan dengan memberikan dukungan sosial bagi siswa, khususnya pada siswa SMA. Salah satu cara praktis yang dapat dilakukan untuk meningkatkan persepsi dukungan sosial ialah dengan mengadakan aktivitas untuk mengenal orangorang di lingkungan sekolah, aktivitas-aktivitas yang melibatkan interaksi secara langsung dengan guru, teman sekelas, atau sahabat melalui kegiatan di dalam kelas atau kegiatan ekstrakurikuler di luar kelas. 
Guru memegang peran sentral dalam memenuhi kebutuhan dukungan sosial siswa, sehingga penting untuk mempertahankan dan meningkatkan hubungan maupun interaksi dengan siswa. Ini dapat dilakukan dengan memberikan dukungan apabila siswa membutuhkan informasi, memberikan dukungan emosional berupa memberikan motivasi, perhatian, mendengarkan, dan membantu permasalahan yang dialami, maupun dukungan agar siswa mampu untuk berinteraksi dengan teman di dalam dan di luar kelas dengan melibatkan siswa untuk mengikuti kegiatan dan aktivitas kelompok dengan teman sebaya mereka.

\section{REFERENSI}

Akturk, A. O. (2015). Analysis of cyberbullying sensitivity levels of high school students and their perceived social support levels. Emerald, 12(1), 44-61.

Allardt, E. (1989). An updated indicator system: Having, loving, being. University of Helsinki: Finland.

Azwar, S. (2015). Penyusunan skala psikologi (2nd ed.). Yogyakarta: Pustaka Pelajar.

Danielsen, A. G., Samdal, O., Hetland, J., \& Wold, B. (2009). School-related social support and students' perceived life satisfaction. The Journal of Educational Research, 102(4), 303320.

Deci, E. L., \& Ryan, R. M. (1985). Intrinsic motivation and self-determination in human behavior. New York, NY: Plenum.

Huebner, S. E., \& McCullough, G. (2000). Correlates of school satisfaction among adolescents. The Journal of Educational Research, 93(5), 331-335.

Konu, A., \& Koivisto, A. M. (2011). The school well-being profile - A valid instrument for evaluation. Paper presented at the Conference: EDULEARN11 - Barcelona 2011. Ditemu kembali dari https://www.researchgate.net/publication/230805981_The_School_WellBeing_Profile_-_a_valid_instrument_for_evaluation

Konu, A., \& Lintonen, T. P. (2006). School well-being in grades 4-12. Health Education Research, 21(5), 633-642.

Konu, A., \& Rimpela, M. (2002). Well-being in school: A conceptual model. Health Promotion International, 17(1), 79-87. 
Liu, W., Mei, J., Tian, L., \& Huebner, E. S. (2016). Age and gender differences in the relation between school-related social support and subjective well-being in school among students. Social Indicators Research, 125(3), 1065-1083.

Malecki, C. K., \& Demaray, M. K. (2003). What type of support do they need? Investigating student adjustment as related to emotional, informational, appraisal, and instrumental support. School Psychology Quarterly, 18, 231-252.

Malecki, C. K., Demaray, M. K., \& Elliott, S. N. (2014). A working manual on the development of the child and adolescent social support scale (2000). DeKalb, IL: Northern Illinois University.

Munoz-Laboy, M., Severson, N., Perry, A., \& Guilamo-Ramos, V. (2013). Differential impact of types of social support in the mental health of formerly incarcerated latino men. Am J Mens Health, 8(3), 226-239.

Nanda, A., \& Widodo, P. B. (2015). Efikasi diri ditinjau dari school well-being pada siswa Sekolah Menengah Kejuruan di Semarang. Jurnal Empati, 4(3), 90-95.

Nidianti, W. E., \& Desiningrum, D. R. (2015). Hubungan antara school well-being dengan agresivitas. Jurnal Empati, 4(1), 202-207.

Pusat Data dan Statistik Pendidikan dan Kebudayaan. (2017). Ikhtisar data pendidikan dan kebudayaan 2017/18. Jakarta: Kementerian Pendidikan dan Kebudayaan.

Santrock, J. W. (2014). Psikologi pendidikan. Jakarta: Salemba Humanika.

Sarwono, S. W. (2015). Psikologi remaja. Jakarta: Raja Grafindo.

Tian, L., Liu, B., Huang, S., \& Huebner, E. S. (2013). Perceived social support and school wellbeing among Chinese early and middle adolescents: The mediational role of self-esteem. Social Indicators Research, 113(3), 991-1008.

Tobia, V., Greco, A., Steca, P., \& Marzocchi. (2019). Children's well-being at school: A multidimensional and multi-informant approach. Journal of Happiness Studies, 20(3), 841-861

Tomyn, A. J., \& Cummins, R. (2010). The subjective well-being of high-school students: Validating the personal well-being index-School children. Social Indicators Research, 101(3). doi: 10.1007/s11205-010-9668-6

Vedder, P., Boekaerts, M., \& Seegers, G. (2005). Perceived social support and well-being in school: The role of students' ethnicity. Journal of Youth and Adolescence, 34(3), 269-278. 